\title{
Radiomics in Radiation Oncology Precision Medicine
}

\author{
*Fawzi Abuhijla, Pablo Munoz and Fabio Moraes \\ Department of Radiation Oncology, Princess Margaret Cancer Centre, Toronto, Canada
}

Submission: May 08, 2017; Published: May 10, 2017

"Correspondence Address: Fawzi Abuhijla, Department of Radiation Oncology, Princess Margaret Cancer Centre, Toronto, Canada, Email:fawzi.abuhijla@gmail.com

\section{Commentary}

Radiomics is emerging domain, which have been evolved in the last decade to provide answers to selected questions in the context of precision medicine. Radiomics is defined as the highthroughput extraction of large amounts of image features from radiographic image. Radiomics work flow involves: Imaging, segmentation, feature extraction and analysis [1]. It opens the opportunity of using the current patient radiological imaging to extrapolate data by creating models to predict disease behavior in future patients [2].

Evidence based medicine generalize guidelines and protocols based on updated publications and clinical trials. However, these guidelines are amenable to change and don't predict outcome in individualized level. The use of radiomics in oncology in precision medicine era, offers a personalized decision for selecting: chemotherapy agents, immunotherapy and radiotherapy modality, dose and margins.

Radiomics purposes to allocate a group of features that accurately anticipate patient outcome in an individualized fashion. These outcomes are related to disease as: tumor local, regional and systemic control or related to the patient as: quality of life and treatment toxicity. Predicting these outcomes would help the oncologist and the patient in better selection for the treatment options based on radiomics predicted outcomes [3]. Challenges for implementing the use of Radiomics are: the

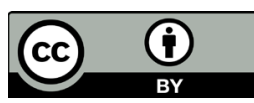

This work is licensed under Creative Commons Attribution 4.0 License DOI: $10.19080 /$ CTOIJ.2017.05.555653 change in features on different radiological techniques [4], segmentation by manual delineation leads to discrepancy in features extraction [5], in addition to the variation in software execution for features extraction.

Although there has been increase in the number of studies on radiomics, it is still in its early phase and more data is needed. Standardizing the imaging modalities and quality assurance with good communication between different disciplines involving physicians, physicist, mathematicians and engineers would lead to further step in the right direction and improve the outcomes of radiomics.

\section{Reference}

1. Lambin, P (2012) Radiomics: extracting more information from medical images using advanced feature analysis. Eur J Cancer 48(4): 441-446.

2. Gillies RJ, PE Kinahan, H Hricak (2016) Radiomics: Images Are More than Pictures, They Are Data. Radiology 278(2): 563-577.

3. Lambin P (2013) Predicting outcomes in radiation oncology-multifactorial decision support systems. Nat Rev Clin Oncol 10(1): 27 40.

4. Oliver JA (2015) Variability of Image Features Computed from Conventional and Respiratory-Gated PET/CT Images of Lung Cancer. Transl Oncol 8(6): 524-534.

5. Larue RT (2017) Quantitative radiomics studies for tissue characterization: a review of technology and methodological procedures. Br J Radiol 90(1070).

Your next submission with Juniper Publishers
will reach you the below assets
- Quality Editorial service
- Swift Peer Review
- Reprints availability
- E-prints Service
- Manuscript Podcast for convenient understanding
- Global attainment for your research
- Manuscript accessibility in different formats
( Pdf, E-pub, Full Text, Audio)
- Unceasing customer service
Track the below URL for one-step submission
https://juniperpublishers.com/online-submission.php

